\title{
Immediate effect of intertidal non-mechanised cockle harvesting on macrobenthic communities: a comparative study
}

\author{
FRANCISCO MIGUEL SOUSA LEITÃO and MIGUEL BAPTISTA GASPAR \\ Instituto Nacional de Investigação Agrária e das Pescas (INIAP/IPIMAR), Centro Regional de Investigação Pesqueira \\ do Sul (CRIPSul), Avenida 5 de Outubro s/n, P-8700-305 Olhão, Portugal. E-mail: fleitao@cripsul.ipimar.pt
}

\begin{abstract}
SUMMARY: In Ria Formosa cockles (Cerastoderma edule) have traditionally been harvested with a harvesting-knife (HK). However, over the last six years there has been an increase in the use of a hand-dredge (HD) to exploit cockle beds. A comparative study on the impact of these harvesting methods on the benthic macrofauna was undertaken with the aim of evaluating the possible introduction of the hand-dredge in the fishery. Macrofaunal mortality was very low regardless of the gear. However, the total mortality resulting from using the HK was superior to the one observed for the HD. For the same fishing time the hand-dredge covers an area approximately five times greater that the one covered by the knife, with the former yielding 5 times the catch of the latter. Consequently, the use of hand-dredges increases the fishing effort, which may lead to the overexploitation of the cockle populations. Our results revealed that the immediate effect of both gears on macrobenthic communities was similar and minimal. Therefore, we believe that introducing the hand-dredge in the cockle fishery should only be authorised if other management measures, such as daily quotas, closed areas and limiting the number of fishing licenses, are implemented.
\end{abstract}

Keywords: Cerastoderma edule, cockle, fishing effect, hand dredging, harvesting knife, Ria Formosa.

RESUMEN: IMPACTO DE LA PESCA DEL BERBERECHO CON ARTES NO MECANIZADAS EN LAS COMUNIDADES MACROBENTÓNICAS DE ZONAS INTERMAREALES: UN ESTUDIO COMPARATIVO. - En la Ría Formosa los berberechos (Cerastoderma edule) han sido tradicionalmente recolectados con un cuchillo de marisqueo. Pero en los últimos seis años ha habido un crecimiento en el uso del rastro de mano en la explotación de los bancos de berberechos. Se ha desarrollado un estudio comparativo sobre el impacto de estos métodos de pesca en la macrofauna bentónica con el objetivo de evaluar una posible introducción de este arte de pesca ilegal. La mortalidad de la macrofauna ha sido muy baja, independientemente de los métodos de pesca utilizados. No obstante, la mortalidad total, resultante del uso del cuchillo de marisqueo, es superior a la que se ha observado con el uso del rastro de mano. Para el mismo tiempo de pesca, el rastro cubre aproximadamente una área cinco veces mayor que el del cuchillo. En consecuencia, el uso del rastro de mano aumenta el esfuerzo de pesca, lo que puede llevar a la sobreexplotación de las poblaciones de berberechos. Nuestros resultados revelan que el efecto inmediato de ambos artes en las comunidades macrobentónicas ha sido semejante y mínimo. Concluimos que la introducción del rastro en la pesca de berberechos sólo debería autorizarse si fueran implementadas otras medidas de gestión de la pesca, como las restricciones diarias de las capturas, áreas cerradas y limitaciones en el número de permisos de pesca.

Palabras clave: Cerastoderma edule, berberechos, impactos de la pesca, rastro de mano, cuchillo de marisqueo, Ría Formosa.

\section{INTRODUCTION}

Harvesting marine invertebrates from intertidal and estuarine habitats occurs all over the world, and supports the subsistence of many small fishing communities. Traditionally, in intertidal areas, harvesting of bivalves has been undertaken by hand or using rudimentary fishing artefacts. However, in some countries traditional collection methods have been superseded by mechanised methods 
such as tractor dredging, suction dredging or hydraulic dredging techniques (Hall and Harding, 1997; Ferns et al., 2000). There is a growing concern and considerable debate within the scientific community concerning both the magnitude of the impact of these mechanical methods on habitat complexity and the ability of harvested areas to recover. However, if the high number of harvesters involved in the cockle fishery is taken into consideration, the impacts of non-mechanised cockle harvesting on the ecosystem should also be considered since they could produce similar environmental effects as mechanical harvesting. In Ria Formosa, a coastal lagoon located in the Algarve coast (southern Portugal), bivalve species have been harvested since ancient times (Ruano, 1997). Among the species that are harvested, the cockle (Cerastoderma edule) is one of the most significant. Historically, cockle harvesting has been carried out by hand over extensive beds that are exposed during low tide, with fishermen digging and overturning the sediment, using a local traditional fishing gear called a harvesting-knife (HK). However, over the last six years an increasing use of hand-dredges (HD) for cockles has been recorded, despite being an illegal fishing gear according to the Ria Formosa Natural Park's present regulation. As a result of HD usage, conflicts have arisen between fishermen using traditional methods (HK) and those using the HD. HK fishermen argue that using hand dredges inside the lagoon causes a huge impact on the macrofauna. HD fishermen believe that this impact is minimal and similar to the impact induced by the HK, since the HD catches are almost exclusively composed of cockles. Nevertheless, no one has yet assessed the effects of the two fishing methods on the ecosystem.
Despite the importance of the cockle fishery, the Ria Formosa is also an area of considerable conservational importance, primarily for its expanse of intertidal habitats and saltmarshes. This reinforces the need to assess the environmental impacts of this fishery. The ecological effects of cockle harvesting using mechanical methods are well documented (e.g. Moore, 1991; Rostron, 1993; Rostron, 1995; see review by Rees, 1996; Hall and Harding, 1997; Ferns et al., 2000; Piersma et al., 2001), whereas studies on the impacts of non-mechanical methods (such as the harvesting techniques used in Ria Formosa or hand raking) on the ecosystem (e.g. Spencer, 1996; Kaiser et al., 2001) are scarce. Cockle beds are inhabited by a variety of other benthic organisms (non-target species) and thus, similarly to other fisheries, harvesting causes disturbances to associated macrobenthic fauna (e.g. Beukema, 1995; Kaiser, et al., 1998; Gaspar et al., 2003). Moreover, removing, damaging or killing some species from a community can alter its structure in the short and/or long term (e.g. Hall et al., 1993; Dayton et al., 1995; Philippart, 1998; Ferns et al., 2000). However, these effects depend on a variety of factors, such as the fishing gear, bottom type, site exposure, benthic community structure, intensity and scale of habitat disturbance (e.g. Goñi, 1998; Agardy, 2000; Kaiser et al., 2001; Gislason, 2003). Therefore, implementing a sustainable-use policy requires a profound knowledge of the impacts that the cockle fishery can provoke on the ecosystem. The aim of the present paper is to examine and compare harvested areas, fishing yields and the immediate impact of the cockle fishery on the benthic community in relation to using the harvesting-knife or hand-dredge.

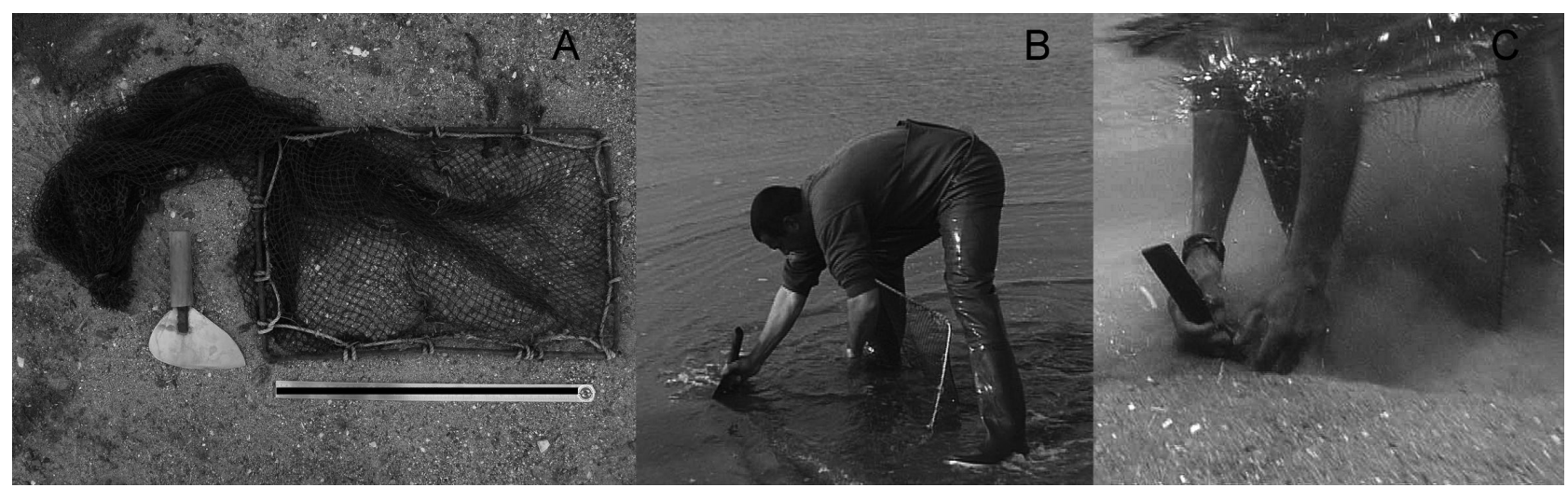

FIG. 1. - Photographs of the harvesting knife and net bag used in the cockle fishery (A), the way that it is operated (B) and underwater photograph of the harvesting knife during harvesting $(\mathrm{C})$. scale bar $=50 \mathrm{~cm}$. 


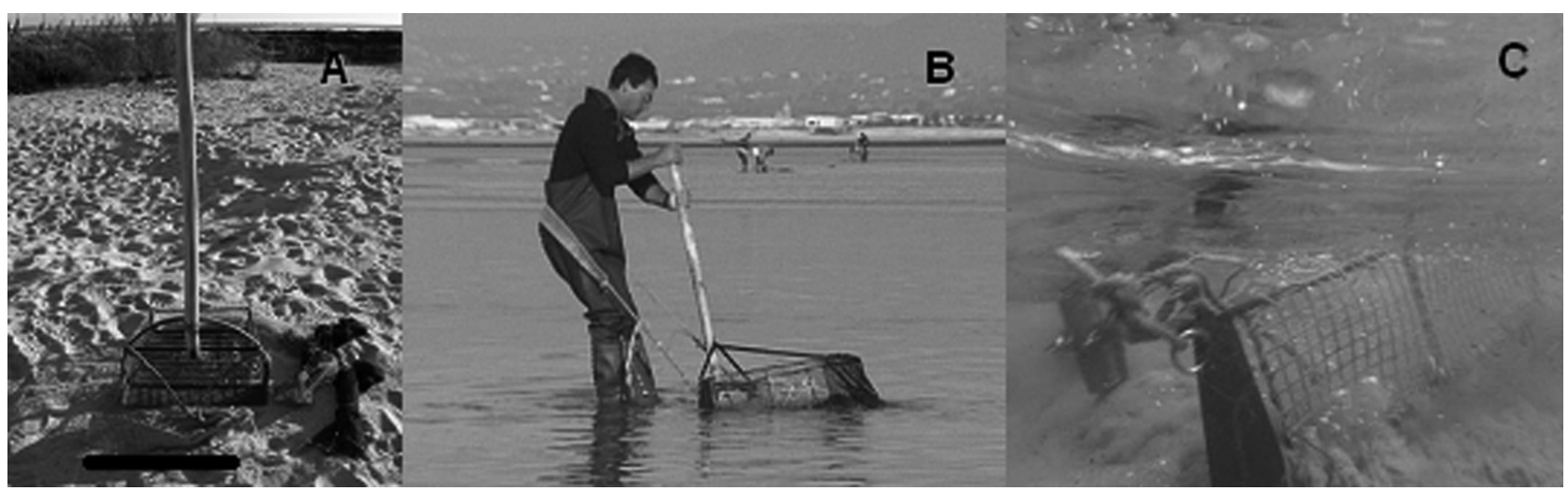

FIG. 2. - Photographs of the hand dredge used in the cockle fishery (A), the way the gear is operated (B) and underwater photograph of the hand dredge during harvesting $(\mathrm{C})$. scale bar $=50 \mathrm{~cm}$.

\section{METHODS}

\section{Description of fishing gears}

\section{Harvesting-knife (HK)}

The HK (Fig. 1) is made of a wooden handle and a blade with a cutting edge, shaped to allow sediment to be dug up then pushed into a diamond mesh bag tied onto a rectangular iron structure, called locally "xalavar".

\section{Hand-dredge (HD)}

The hand-dredge (Fig. 2) consists of a rectangular iron grid with two apertures on opposite sides. One of the apertures, the gear mouth, allows the clam to enter the dredge, and the other is attached to a $25 \mathrm{~mm}$ diamond mesh bag that retains the clams that do not escape through the grid bars. The 3.5metre long net bag ends with a simple knot that can be easily unfastened to remove the catch from the codend. A 1-1.2 m long wooden pool is fixed to the grid to facilitate the gear being towed over the sediment surface. Despite its weight, this gear is easily handled once set on the ground.

\section{Sampling design}

Fieldwork was carried out during February 2004 on the sandflats located in front of Culatra Island (Fig. 3). In this area, the substratum is composed of clean sandy grounds and uniform topography. Although this zone is characterised by relatively high cockle densities, it was not fished for one year (at the beginning of the experiment) for the commercial harvesting of cockles. Therefore, the associated macrobenth-

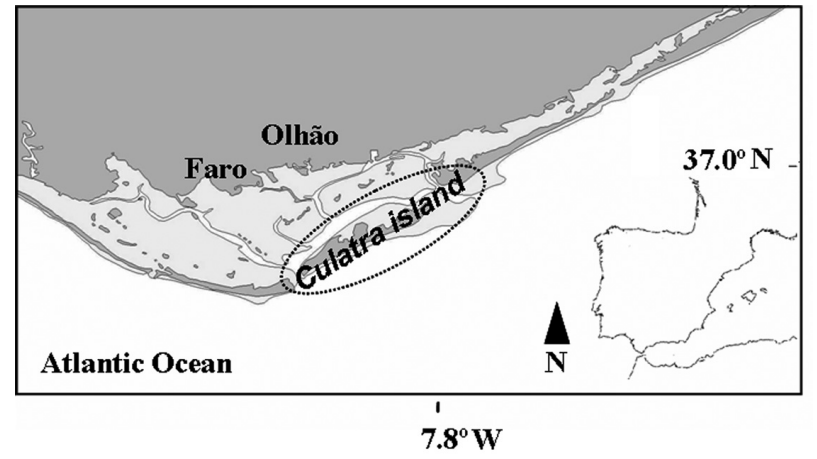

FIG. 3. - Map showing the geographical location of the Ria Formosa lagoon and the sampling site (dotted ellipse).

ic fauna were considered to be representative of what is normally associated with cockles. An area of $100000 \mathrm{~m}^{2}(1000 \times 100 \mathrm{~m})$ was subdivided into quadrats of $50 \times 50 \mathrm{~m} .27$ quadrats were chosen randomly and given a label, also randomly $(\mathrm{C}$, control; HK, harvest-knife; and HD, hand-dredge). The experimental design incorporated 9 control quadrats and 18 fished quadradts ( 9 for each fishing gear). In order to determine the immediate impact of cockle harvesting, macrofauna samples were collected before and immediately after fishing operations (performed by professional fishermen) both in control and fished plots. It is important to note that it was initially planned to collect samples one week and one month after the fishing operations; however, since this area started being heavily fished immediately after the beginning of the experiment, it was impossible to proceed with the surveys. For each area sampled, 18 sediment corers were collected using a PVC cylinder (100 mm diameter $\times 120 \mathrm{~mm}$ deep). In the preset study, macrofauna was defined as the organisms retained by a $1 \mathrm{~mm}^{2}$ mesh sieve. Therefore, the cores were washed in situ over a $1 \mathrm{~mm}$ mesh and the residue preserved in a solution of $4 \%$ buffered formalin. In 
order to delimit the harvested area, fishermen were asked to fish for ten minutes in a straight line. At the end of each fishing operation the fished area was determined. For each experimental fishing operation, the catch was weighed and a sub-sample was collected in order to estimate the proportion of damaged individuals that were retained. In the laboratory, the catch sub-samples and macrofauna from corers were sorted, counted and identified to the species level whenever possible. Each organism caught within the fished quadrats was given a physical damage score according to the arbitrary damage scale used by Gaspar et al. (2003). This scale comprises four scores, where score 1 corresponds to individuals in perfect condition; score 2 corresponds to specimens with a low degree of lesions; score 3 corresponds to heavily damaged individuals and score 4 to dead individuals. Organisms with score 3 were considered as having their survival impaired; therefore, mortality was estimated taking into account individuals scored with 3 and 4 . It is important to point out that this experiment was conducted at low-tide level.

\section{Data analysis}

\section{Comparison between fishing gears}

One-way ANOVA parametric assumptions were tested and univariate analysis $(\alpha=0.05)$ was performed to assess differences between harvested area/fishing time (10 min.) and fishing yields (per fishing time and $\mathrm{m}^{2}$ ) and to test the effect of the harvest method on macrofauna mortality. Alternatively, whenever normality (Kolmogorov-Smirnov test) and/or heterogeneity (Bartlett test) assumptions failed, the non-parametric Kruskal-Wallis test was used. The Statistica (v. 5.0) software package was used in all univariate analysis. ANOSIM (ANOVA of similarity) was used to test for significant differences between catch compositions from each gear (Primer 5.1; Clarke and Warwick, 1994). In order to evaluate gear selectivity properties, the cockle length frequency distributions from both gears were compared using the Kolmogorov-Smirnov test $(\alpha=$ 0.05), following Zar (1996).

\section{Immediate fishing impact on macrobenthic community}

Similarity between samples was analysed by cluster (group-average linkage method) analysis fol- lowed by multi-dimensional scaling (non-metric MDS) based on the Bray-Curtis similarity coefficient after square root transformation of the faunal data. Species with the greatest contribution to dissimilarity between areas and sample periods were determined using the similarity percentages routine (SIMPER). Significant differences between the treatment and control plots in each sampling period were determined using an a priori one-analysis of similarities (ANOSIM). Multivariate analyses were performed using the PRIMER v5.0 software package (Clarke and Gorley, 2001).

\section{RESULTS}

\section{Comparison of fishing gears}

The differences found between HK and HD fisheries became evident regarding the harvested area per fishing time (Fig. 4A). For the same fishing time (10 min.) the area harvested by the HD was significantly higher (ANOVA: $F=51.52 ; \quad P<0.001$ ), approximately 5 times greater, than the area covered by the HK. On average, per 10 minutes of work a fisherman using the HD fished an area of $91 \pm 25$ $\mathrm{m}^{2}$, whilst an area of $18 \pm 11 \mathrm{~m}^{2}$ was covered with the HK. Thus, and as expected, the mean fishing yield per time (Fig. 4B) was also significantly higher (ANOVA: $F=5.3 ; P=0.034$ ) when the HD was used. However, the mean fishing yield per time was not proportionally higher when compared to the differences found between the harvested areas. The mean fishing yield per time for both HK and HD was $12.4 \pm 5$ and $40.7 \pm 29 \mathrm{~kg} / 10 \mathrm{~min}$. respectively. Despite the differences found in relation to the harvested areas and yields per time, non-significant differences (ANOVA: $F=0.387 ; P=0.567$ ) were found between gears in terms of the mean yields per $\mathrm{m}^{2}$, which were slightly higher when the HK was used. The mean fishing yield per $\mathrm{m}^{2}$ was $0.86 \mathrm{~kg} / \mathrm{m}^{2}$ for the HK and $0.59 \mathrm{~kg} / \mathrm{m}^{2}$ for the HD (Fig. 4C). This difference is related to the length composition of the cockle catches (Fig. 5). The length-frequencies of the catches from the two fishing gears differed significantly due to a higher number of undersized individuals (below the minimum landing size, MLS $=25 \mathrm{~mm})$ in the HK catches $\left(\mathrm{D}^{\prime}\right.$ est $=0,44>\mathrm{D}^{\prime}$ $(\alpha=0.05), H_{0}: F_{\mathrm{A}}(\mathrm{x})=F_{\mathrm{B}}(\mathrm{X})$ is rejected). These differences are explained by the smaller mesh $(15 \mathrm{~mm})$ of the "xalavar" of the HK when compared with the 

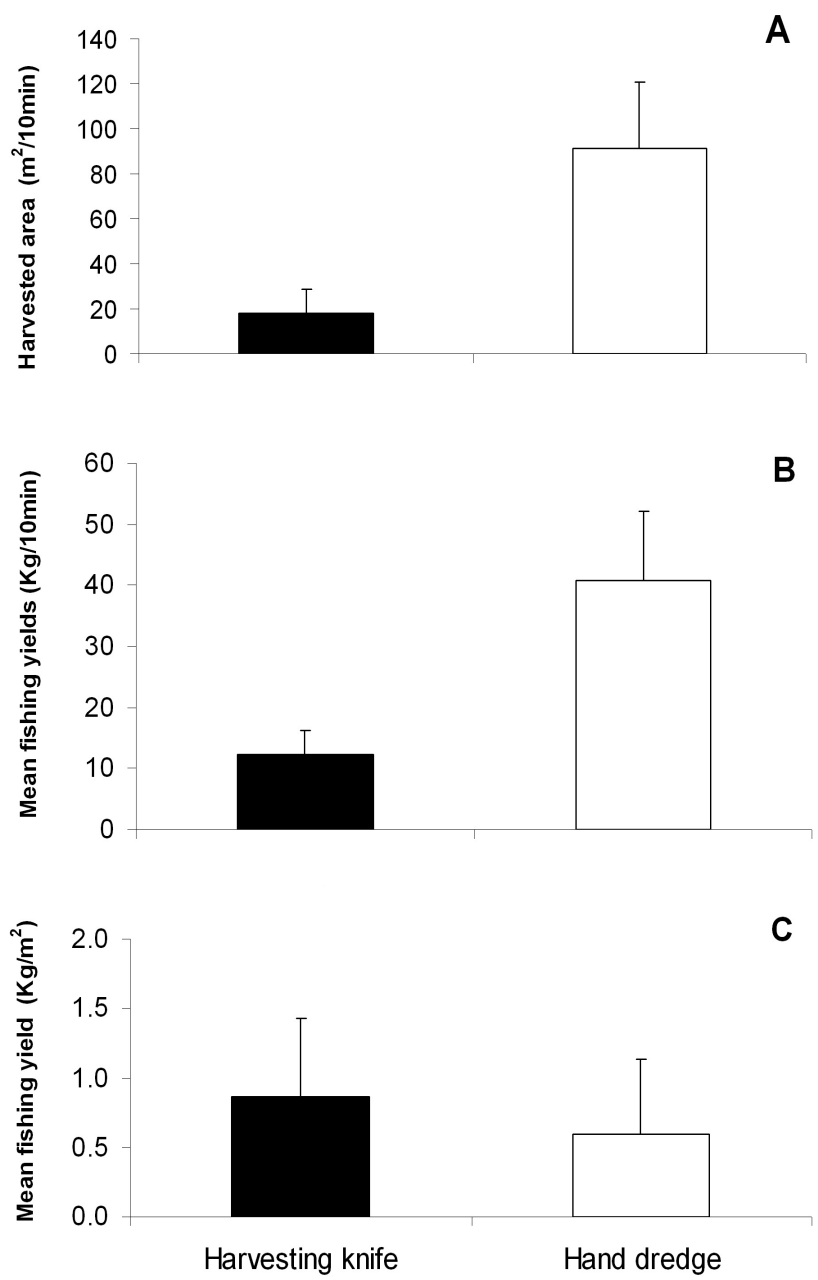

FIG. 4. - Comparison of the mean harvested area ( $\mathrm{m}^{2} / 10 \mathrm{~min}$.) (A), mean fishing yields (kg/10 min.) (B) and mean fishing yields per area $\left(\mathrm{kg} / \mathrm{m}^{2}\right)(\mathrm{C})$ for the harvesting knife and hand dredge.

mesh size of the HD net bag $(25 \mathrm{~mm})$. Nevertheless, considering that no cockle under the minimum length size is landed, the mean fishing yield $\left(\mathrm{kg} / \mathrm{m}^{2}\right)$ for both gears was similar $\left(0.35 \mathrm{~kg} / \mathrm{m}^{2}\right.$ and 0.31

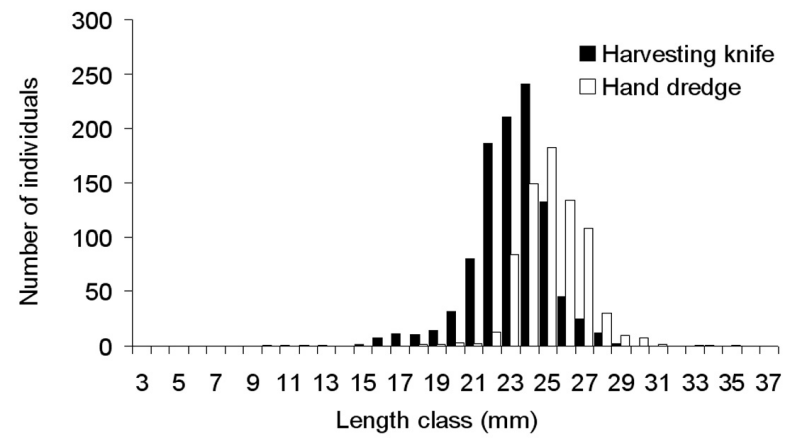

FIG. 5. - Cerastoderma edule. Length frequency distributions for the harvesting knife and hand dredge catches.

$\mathrm{kg} / \mathrm{m}^{2}$ for HD and HK respectively). Moreover, for the same fishing time the fishing yields from both gears are proportional to the area harvested, that is, yields from the HD are 5 times greater than yields from the HK.

Cockles composed most of the catch for both fishing gears. Therefore, a small number of species and individuals were incidentally caught, resulting in a low by-catch percentage (Table 1). Indeed, the by-catch was lower than $1 \%$. Non-significant differences were registered in terms of catch composition between gears (ANOSIM: $R=0.25 ; P=0.9$ ). The occurrence in the catches of other commercial species, namely Ruditapes decussatus and Venerupis aurea, which are also exploited in the lagoon, was also negligible. None of the by-catch individuals suffered mortality. The target species was the sole species affected, even so the number of dead individuals was very low, never reaching $0.5 \%$ of the cockle catches for either gear.

The mortality of the individuals remaining in the fished area was also very low for both fishing gears. Although statistical analysis showed non-significant differences between HK and HD mortality (K-W:

TABLE 1. - Overall by-cacth, mean by-catch per $\mathrm{m}^{2}$ fished and proportion of individuals retained taking into consideration the background density estimated for each by-catch species recorded in the catches of the harvesting knife and hand dredge.

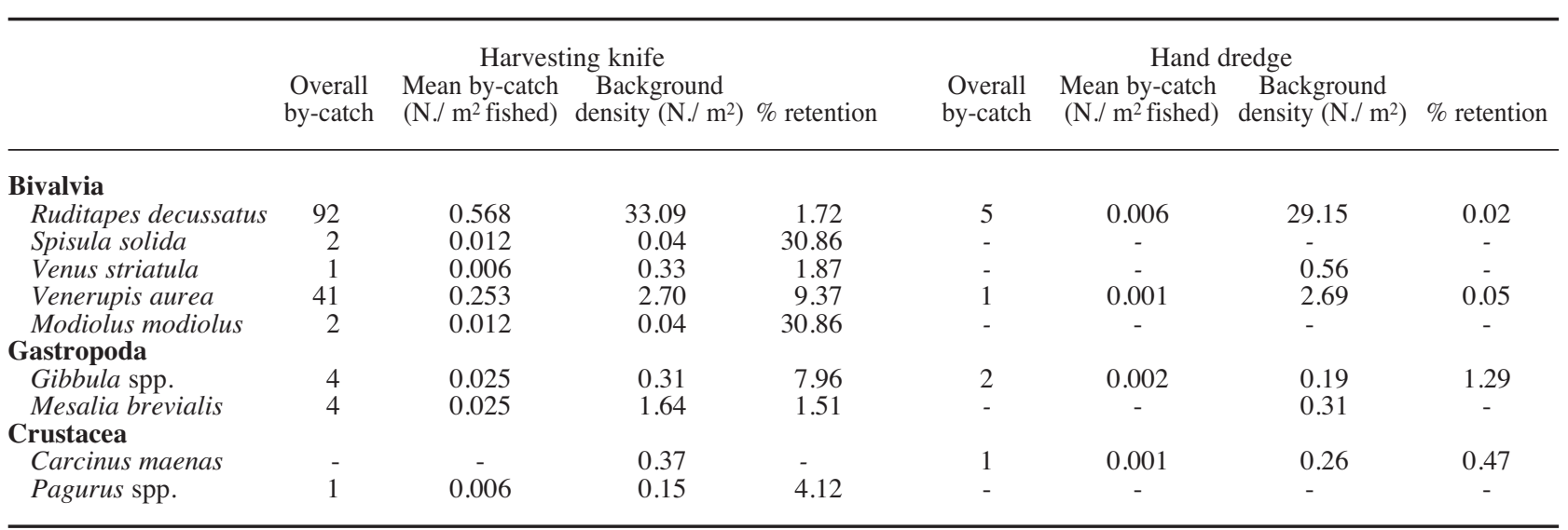


TABLE 2. - Mean number and mean proportion of dead individuals per $\mathrm{m}^{2}$ estimated for each taxon and harvesting method.

\begin{tabular}{|c|c|c|c|c|c|c|c|}
\hline & & N. ind. & $\begin{array}{l}\text { Harvesting Knife } \\
\text { Mortality }\left(\mathrm{n}^{\circ}\right)\end{array}$ & Mortality $(\%)$ & N. ind. & $\begin{array}{l}\text { Hand dredge } \\
\text { Mortality }\left(\mathrm{n}^{\circ}\right)\end{array}$ & Mortality(\%) \\
\hline Anthozoa & Actiniaria & 0.75 & 0.00 & 0.00 & 0.12 & 0.00 & 0.00 \\
\hline Annelida & Polychaeta & 41.06 & 0.00 & 0.00 & 23.49 & 0.00 & 0.00 \\
\hline Bivalvia & $\begin{array}{l}\text { Abra spp. } \\
\text { Cerastoderma edule } \\
\text { Dosinia exoleta } \\
\text { Donax semistriatus } \\
\text { Gouldia minima } \\
\text { Loripes lucinalis } \\
\text { Modiolus modiolus } \\
\text { Nucula minuta } \\
\text { Ruditapes decussatus } \\
\text { Spisula solida } \\
\text { Spisula subtruncata } \\
\text { Tellina tenuis } \\
\text { Venerupis pullastra } \\
\text { Venus striatula } \\
\text { Venerupis aurea } \\
\text { Total Bivalvia }\end{array}$ & $\begin{array}{c}100.99 \\
350.22 \\
0.37 \\
0.06 \\
- \\
1.18 \\
0.04 \\
0.06 \\
33.09 \\
0.04 \\
9.16 \\
2.62 \\
2.37 \\
0.33 \\
2.70 \\
503.22\end{array}$ & $\begin{array}{l}6.23 \\
5.37 \\
0.00 \\
0.00 \\
- \\
0.00 \\
0.00 \\
0.00 \\
0.25 \\
0.00 \\
0.00 \\
0.44 \\
0.31 \\
0.00 \\
0.01 \\
12.60\end{array}$ & $\begin{array}{l}6.17 \\
1.53 \\
0.00 \\
0.00 \\
- \\
0.00 \\
0.00 \\
0.00 \\
0.75 \\
0.00 \\
0.00 \\
16.67 \\
13.16 \\
0.00 \\
0.40 \\
2.50\end{array}$ & $\begin{array}{c}85.54 \\
276.90 \\
0.19 \\
- \\
0.06 \\
0.44 \\
- \\
- \\
29.15 \\
- \\
4.11 \\
3.12 \\
8.85 \\
0.56 \\
2.69 \\
411.59\end{array}$ & $\begin{array}{l}1.68 \\
3.76 \\
0.00 \\
- \\
0.00 \\
0.00 \\
- \\
- \\
0.19 \\
- \\
0.00 \\
0.12 \\
0.06 \\
0.00 \\
0.00 \\
5.82\end{array}$ & $\begin{array}{l}1.97 \\
1.36 \\
0.00 \\
- \\
0.00 \\
0.00 \\
- \\
- \\
0.64 \\
- \\
0.00 \\
4.00 \\
0.70 \\
0.00 \\
0.00 \\
1.41\end{array}$ \\
\hline \multicolumn{2}{|c|}{ Branchiostomidae } & 0.12 & 0.00 & 0.00 & 0.06 & 0.00 & 0.00 \\
\hline Crustacea & $\begin{array}{l}\text { Bathyporeia spp. } \\
\text { Carcinus maenas } \\
\text { Cirolanidae } \\
\text { Corophium spp. } \\
\text { Cyathura carinata } \\
\text { Pagurus spp. } \\
\text { Palaemon serratus } \\
\text { Pinnotheres pisum } \\
\text { Sphaeroma spp. } \\
\text { Upogebia deltaura } \\
\text { Tanaidacea } \\
\text { Total Crustacea }\end{array}$ & $\begin{array}{l}0.62 \\
0.37 \\
0.37 \\
0.06 \\
6.42 \\
0.15 \\
0.37 \\
0.06 \\
1.62 \\
0.25 \\
0.19 \\
10.49\end{array}$ & $\begin{array}{l}0.12 \\
0.06 \\
0.00 \\
0.00 \\
0.06 \\
0.00 \\
0.19 \\
0.06 \\
0.12 \\
0.12 \\
0.00 \\
0.75\end{array}$ & $\begin{array}{c}20.00 \\
16.67 \\
0.00 \\
0.00 \\
0.97 \\
0.00 \\
50.00 \\
100.00 \\
7.69 \\
50.00 \\
0.00 \\
7.13\end{array}$ & $\begin{array}{l}1.99 \\
0.26 \\
0.25 \\
0.37 \\
6.98 \\
- \\
0.06 \\
- \\
2.49 \\
0.25 \\
0.31 \\
12.97\end{array}$ & $\begin{array}{l}0.81 \\
0.06 \\
0.00 \\
0.00 \\
0.19 \\
- \\
0.00 \\
- \\
0.12 \\
0.00 \\
0.00 \\
1.18\end{array}$ & $\begin{array}{l}40.63 \\
23.64 \\
0.00 \\
0.00 \\
2.68 \\
- \\
0.00 \\
- \\
5.00 \\
0.00 \\
0.00 \\
9.12\end{array}$ \\
\hline Gastropoda & $\begin{array}{l}\text { Bittium spp. } \\
\text { Calliostoma spp. } \\
\text { Cyclope neritea } \\
\text { Eulina glabra } \\
\text { Gibbula spp. } \\
\text { Haminoea hydatis } \\
\text { Hydrobia ulvae } \\
\text { Mesalia brevialis } \\
\text { Nassarius spp. } \\
\text { Natica spp. } \\
\text { Total Gastropoda }\end{array}$ & $\begin{array}{c}2.68 \\
0.06 \\
0.12 \\
- \\
0.31 \\
0.44 \\
248.46 \\
1.64 \\
0.75 \\
0.25 \\
254.71\end{array}$ & $\begin{array}{l}0.00 \\
0.00 \\
0.00 \\
- \\
0.00 \\
0.00 \\
0.06 \\
0.00 \\
0.00 \\
0.00 \\
0.06\end{array}$ & $\begin{array}{l}0.00 \\
0.00 \\
0.00 \\
- \\
0.00 \\
0.00 \\
0.03 \\
0.00 \\
0.00 \\
0.00 \\
0.02\end{array}$ & $\begin{array}{c}2.74 \\
- \\
0.12 \\
0.06 \\
0.19 \\
0.12 \\
265.10 \\
0.31 \\
0.12 \\
- \\
268.78\end{array}$ & $\begin{array}{l}0.00 \\
- \\
0.00 \\
0.00 \\
0.00 \\
0.00 \\
0.06 \\
0.00 \\
0.00 \\
- \\
0.06\end{array}$ & $\begin{array}{c}0.00 \\
- \\
0.00 \\
0.00 \\
0.00 \\
0.00 \\
0.02 \\
0.00 \\
0.00 \\
- \\
0.02\end{array}$ \\
\hline Holothuroidea & & 1.62 & 0.00 & 0.00 & 1.00 & 0.00 & 0.00 \\
\hline Nemertini & & 2.37 & 0.00 & 0.00 & 2.80 & 0.00 & 0.00 \\
\hline Oligochaeta & & - & - & - & 0.06 & 0.00 & 0.00 \\
\hline Osteichthyes & Pomatoschistus microps & 0.75 & 0.00 & 0.00 & 0.87 & 0.00 & 0.00 \\
\hline Polyplacophor & & 0.12 & 0.00 & 0.00 & 0.06 & 0.00 & 0.00 \\
\hline Sipuncula & & 0.81 & 0.00 & 0.00 & 0.06 & 0.00 & 0.00 \\
\hline Turbellaria & & - & - & - & 0.12 & 0.00 & 0.00 \\
\hline Total & & 815.89 & 13.41 & 1.64 & 721.94 & 7.06 & 0.98 \\
\hline
\end{tabular}

$H=2.964 ; P=0.085)$, the mean mortality was higher for the HK $(2.79 \pm 2.05 \%)$ than the HD $(1.31 \pm$ $0.69 \%)$. Total mortality is the result of the mortality found in the catches plus dead individuals found in the fished area. The overall mortality of the organisms associated with cockle fishery is presented in 
Table 2. Given the low catch mortality and the mortality of the individuals left in the fishing area, the estimated total mortality was also low. Nevertheless, the HK exhibited a slightly higher mortality percentage $(1.64 \pm 2.85 \%)$ than the HD $(0.98 \pm 1.35 \%)$. However, non-significant differences were found between the mean total mortality (ANOVA, $F=4.707 ; P=0.045)$ of the two gears.

Vulnerability to dredging varied considerably between species. Among the taxa present in the samples, 28 did not suffer any damage in relation to either the HD or the HK. The most represented bivalve species in the samples, Cerastoderma edule and Abra spp., were slightly more vulnerable to the HK than to the HD. Amongst the bivalves affected, only Tellina tenuis (16.67\%) and Venerupis pullastra $(13.16 \%)$ presented total mortalities above 6\%, and only for the HK fishery. However, it should be noted, that in numeric terms these species were not abundant. Bivalve species mortality for the HD did not reach over $4 \%$. Nevertheless, overall bivalve mortality was very low for both gears (Table 2).

Assessing the effects of both gears on crustaceans becomes difficult considering that the majority of taxa were poorly represented.
Bathyporeia spp. (20\% and $40.63 \%$ for HK and HD respectively) and Carcinus maenas $(16.67 \%$ and $23.64 \%$ for HK and HD respectively) were affected both by the HK and the HD, whilst Paleomon serratus $(50 \%)$ and Pinnotheres pisum (100\%) suffered higher mortalities when the HK was used. However, average crustacean mortality did not exceed $10 \%$ regardless of the gear.

Due to their shell protection, gastropods were highly resistant to both fishing methods and therefore no mortality was recorded in this group. Mortality was also not observed in any other macrobenthic group present in the samples from HK and HD, namely Anthozoa, Annelidae, Holothuroidea, Nemertini, Oligochaeta, Osteichthyes, Polyplacophora, Sipuncula and Turbellaria.

\section{Immediate fishing effects on the macrobenthic community}

The multivariate analysis (Cluster and MDS; Fig. 6) highlighted five groups. Groups 1, 2, 3 and 5 are composed predominantly by samples collected in the treatment plots after fishing operations, whilst group 4 comprises almost all the samples collected
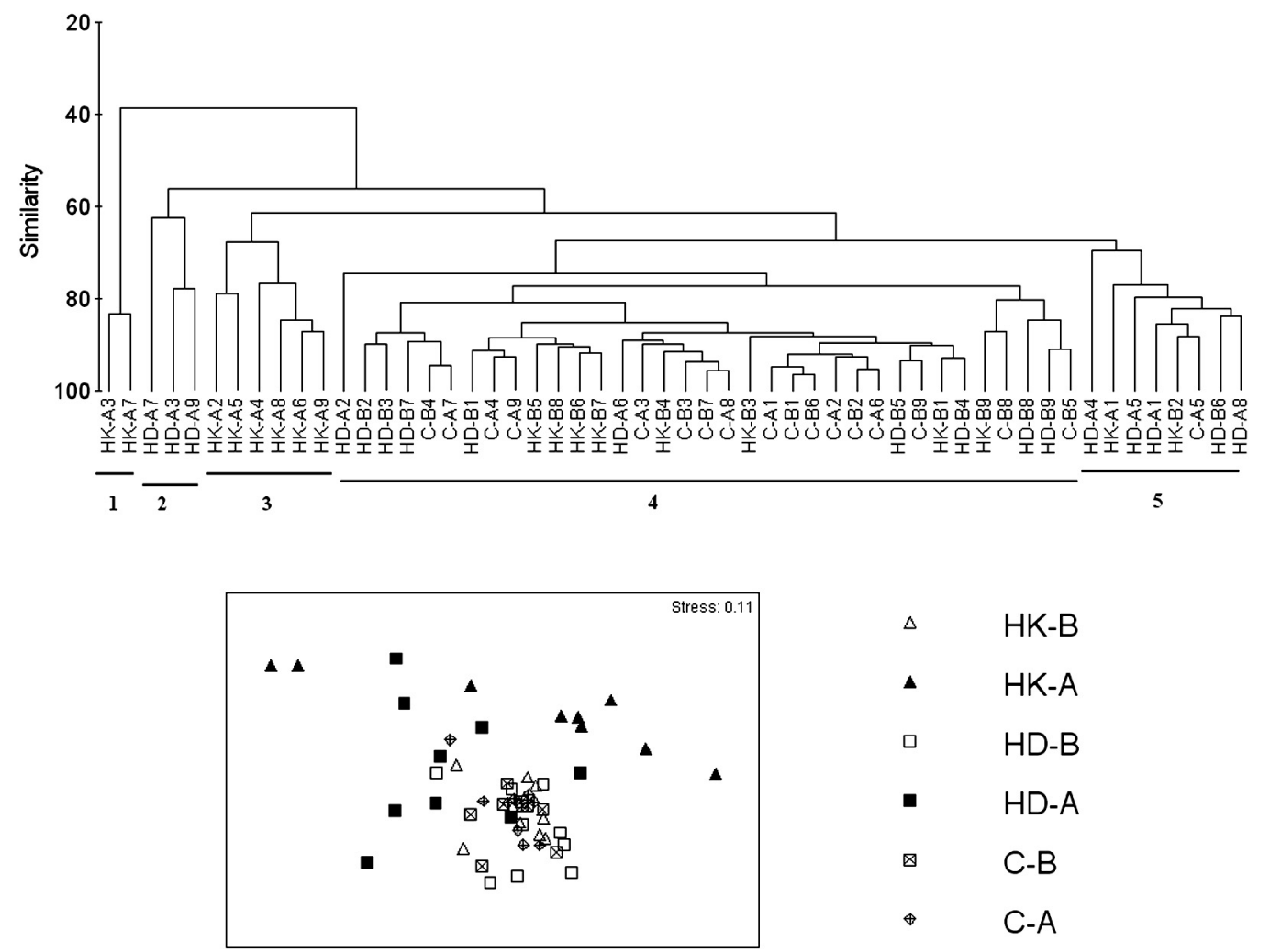

FIG. 6. - Cluster analysis (above) and two-dimensional MDS ordination (below) of community data found in each of the control and treatment areas before and after fishing operations. HK, harvesting knife; HD, hand dredge; C, control; B, before fishing operations; A, after fishing operations. Black symbols: fished areas; clear symbols: unfished areas. 
TABLE 3. - Pair-wise comparisons (ANOSIM) of the benthic community data from control and treatment areas, before and after fishing operations. $\mathrm{HK}$, harvesting knife; $\mathrm{HD}$, hand dredge; $\mathrm{C}$, control; $\mathrm{B}$, before fishing operations; A, after fishing operations; ns, nonsignificant; * $P<0.05$; ** $P<0.001$.

\begin{tabular}{lcccccc}
\hline & C-B & HK-B & HD-B & C-A & HK-A & HD-A \\
C-B & - & ns & ns & ns & $* *$ & $* *$ \\
HK-B & & - & ns & ns & $* *$ & $*$ \\
HD-B & & & - & ns & $* *$ & $*$ \\
C-A & & & & - & $* *$ & $* *$ \\
HK-A & & & & & - & ns \\
\hline
\end{tabular}

in the control plots (before and after fishing) and on the treatment plots before fishing. The SIMPER analysis revealed low dissimilarities $(<20 \%)$ between control and treatment areas before fishing. However, dissimilarities between the samples collected in control (before and after fishing) and treatment areas increased after fishing operations (ranging between $31.5 \%$ and $45.0 \%$ ) mainly due to the decrease in the mean abundance of the target species. The ANOSIM revealed that immediately after fishing, benthic communities from the treatment areas were significantly different from control areas (Table 3). As it was mentioned above, these differences are mainly attributed to the decrease in the mean abundance of cockles in fished areas and therefore we decided to remove the target species from the analysis in order to find out if the benthic communities from treatment and control plots were still different after fishing. However, the ANOSIM test showed that immediately after dredging benthic communities from treatment and control areas did not differ significantly.

\section{DISCUSSION}

Cockle fishery with HD has led to a standing conflict with fishermen that harvest cockles with a HK. The latter argues that the HD fishery causes higher rates of mortality of benthic macrofauna than when the HK is used. However, our results show the opposite. Although non-significant differences in the mortality obtained for the gears assayed was observed, the mean overall macrofauna mortality was higher for the HK. This may be related to the way these gears are operated. Manual dredging is a less disruptive fishing method than digging with a HK. The HD is towed over the sediment surface in such way that the dredge blade cuts the sediment softly to a maximum depth of $5 \mathrm{~cm}$ (Figs. 2 and 7).
In the case of the HK the sediment is sliced to 10-12 $\mathrm{cm}$ depth and pushed into the net bag (Figs. 1 and 7), thus increasing the probability of damaging organisms. For both gears, the individuals that entered the net bag were immediately sieved on the spot and therefore the majority of the non-target specimens could escape. Hence, these organisms can rebury themselves almost immediately, decreasing the risk of being predated (Lindeboom and De Groot, 1998; Gaspar et al., 1999, 2001).

Our results showed significant statistical differences in the composition of the macrobenthic communities before and after fishing in the treatment areas and between these areas (after fishing operations) and the control plots (before and after fishing). However, the SIMPER analysis showed that these differences are mainly due to the decrease in the abundance of cockles after fishing. When the target species was removed from the analysis no significant differences in the benthic communities from treatment and control plots were observed after fishing. Therefore, the immediate effect of both gears on the macrofauna was minimal. The question is if long-term effects can cause changes in community structure. The more persistent the fishing effort on the cockle beds, the higher the probability of macrofauna mortality increasing. The cockle fishery is carried out year-round, but the strategy adopted by the HD and HK fishermen is characterised by a rotational exploitation of the fishing beds. This is related to the fact that fishermen exploit a given area for short periods of time, until catches drop to a nonprofitable yield. This happens after one or two

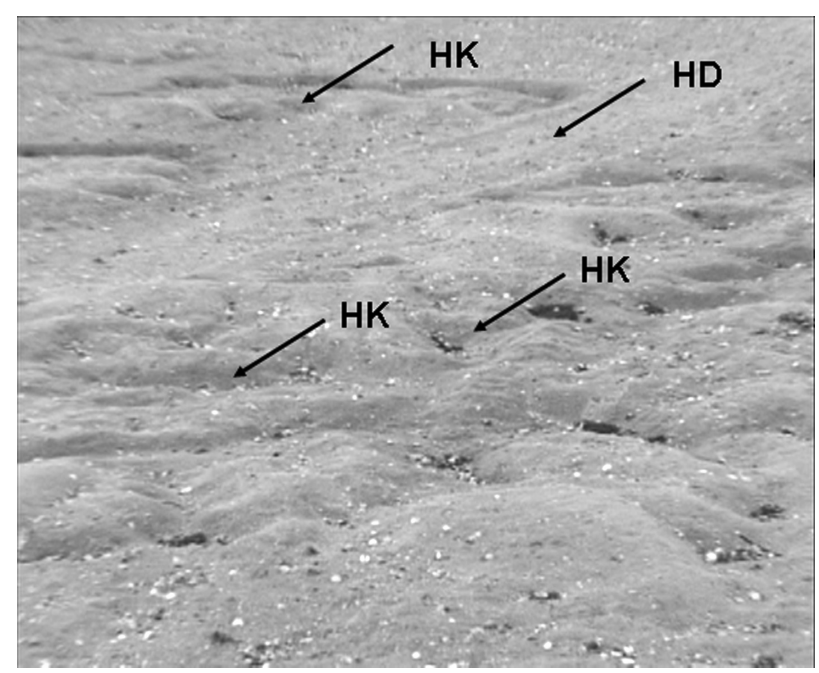

FIG. 7. - Comparison of the scars left on the sediment when the harvesting knife (HK) and the hand dredge are used in the cockle fishery. 
dredge tows, given the gear's high efficiency for cockle harvesting. Therefore, the repeated effect of dredging on a fishing bed is reduced; thus, resulting in a non-intensive exploitation of cockle grounds. Hence, there is no cumulative effect of the fishing activity. A given area is fished again only when cockle yields are profitable, which depends both on the growth rate of juveniles and on their density.

This leads us to wonder if during the growth period from juvenile to adult cockle, macrobenthic fauna can recover. Cockle populations are generally found to be single age-class dominated (Kristensen, 1957). However, since this species spawns partially, several cohorts are found at a given time (Kristensen, 1957; Leitão, 2004). Cockles grow rapidly (Kristensen, 1957; Seed and Brown, 1978), and in the Ria Formosa lagoon, individuals reach maturity within the first year, at 18.6-20 $\mathrm{mm}$ total length (Graça, 2001). Accordingly, Leitão (2004) found at least three well-defined cohorts year-round. However cockle mortality is high in all age-classes, with few cockles surviving beyond the second year (Leitão, 2004). Considering the biological characteristics described above, we believe that a given area will not be fished more than 3-4 times per year. Thus, medium and long-term impacts on the benthic community associated with cockle beds are expected to be minimal considering the low mortalities observed in the present study.

However, other questions arise with the possible introduction of the HD. The two gears operate in distinct areas as far as fishing depth and distance to the main land is concerned. The HK is used near shore in low water depths and on grounds exposed to long emersion periods. Thus, these areas should be protected from hand dredging by implementing closed areas along the lagoon. The HD can be operated on deeper and permanently submerged beds, thus reaching grounds hitherto unexploited by the HK. Such unexploited beds could work as a natural source of larvae and contribute to benthos migration and/or colonisation to surrounding fishing areas. Furthermore, for the same fishing time, the HD harvests an area five times greater than the HK, with yields that are accordingly five times greater. Therefore, since the HD is easier to operate, HD fishermen could be tempted to increase their yields and consequently their incomes. This would result in the area harvested during a tide increasing enormously and the subsequent mortality would also increase. Moreover, hand-dredging is capable of exploiting lower density beds and thus have the potential to over-fish the cockle stocks if adequate management measures are not implemented. Therefore, to overcome these problems, a system of daily quota per fisherman should be implemented. If this cockle fishery becomes quota-regulated, the area covered to achieve the daily quota would be equivalent for both gears, considering that fishing yields per $\mathrm{m}^{2}$ do not differ between gears. Therefore, the main difference between fishing gears will be the time taken to obtain the daily quota. Further, the HK is proportionally more time consuming than the HD so that fishermen have less chance to sieve their catch over the flooding fishing grounds. This may result in the subsequent death of undersized cockles and other macrofaunal organisms exposed to air for long periods and/or discarded in inappropriate grounds.

Fishing with the HK has been carried out for a long time and fishing grounds show no signs of stock depletion and maintain a high productivity rate. Thus, certain sustainability must exist between fishing exploitation and community response capacity, given that communities are usually able to cope with either natural or anthropogenic disturbances (De Alteris et al., 1999). Hall et al. (1993) stressed that if the scale of disturbance induced by the gear is small enough to allow rapid re-colonisation, large-scale effects never become apparent. Several studies have shown that sandy communities have a high capacity to recover from dredge-fishery disturbance (e.g. Kaiser et al., 1998; Spencer et al., 1998). According to Hall et al. (1990), the effects of dredging on local populations are only likely to persist if macrobenthic populations themselves, or sediments in which they inhabit, are immobile or the affected area is large in relation to the remaining habitat, which prevents the dilution effect occurring. For cockle handdredging, we believe that neither of the conditions mentioned above is likely to hold. Moreover, the majority of the species composing the cockle community also inhabit other habitats (Sprung, 1994; Sprung and Machado, 2000), such as the areas in the vicinities of cockle beds. Other authors (Hall et al., 1990; Eleftheriou and Robertson, 1992) have stated that the effects of gear impact on small areas with dynamic habitats, such as sandy sediments, are quickly diluted through the migration of benthos from surrounding areas or through sediment 
redistribution. It is also important to mention, as it has been reported by other authors (Kaiser et al., 2001; Hiddink, 2003), that although sediment is left in situ its cohesive nature can be disrupted because it is churned up and therefore fine particles can be washed away during flooding. Nevertheless, though we have not collected sediment samples we believe that no significant changes in the sediment characteristics occur because the cockle fishery is mainly carried out in sandy sediments that are subject to strong currents.

In a comparative study between the effects of the hydraulic dredge and tractor dredger, Hall and Harding (1997) found that the former gear had a higher impact on the benthic fauna. However, this impact was smothered within 56 days. They pointed out a seasonal community response as the main reason for this recovery. Ferns et al. (2000) studied the impact of a tractor-towed cockle harvester on two intertidal sandy habitats (muddy sand and clean sand) and found that tractor dredging for cockles can cause depletion of non-target populations for several months. They also observed that invertebrate populations in clean sand recovered more quickly that those in muddy sand. This difference in the community recovery was related to its structure, which was more complex in the latter habitat. Spencer (1996) reported site recovery times of 3-4 months and 8 months for hand-raking and suction dredging. A higher reduction in species diversity and abundance was observed when the latter harvest method was used. In a study conducted in the Dee Estuary, Kaiser et al. (2001) demonstrated that recolonisation of sediments disturbed by hand-raking depends on the size of the path. These authors observed that communities in small raked plots recovered 56 days after the disturbance whereas communities in large plots recovered within a year. These works evidence that the adverse effects of cockle harvesting are site specific, depending on several factors such as community structure, size of the area disturbed and harvesting method.

Taking into consideration the results of the present study, we believe that the HD can be used for cockle exploitation without compromising the equilibrium between sustainable exploitation and ecological conservation. However, introducing this fishing gear in the cockle fishery should only be authorised if other management measures, such as daily quotas, closed areas and a limited number of fishing licenses, are implemented.

\section{ACKNOWLEDGEMENTS}

We would like to thank Tata Regala for reviewing and for useful comments on the manuscript. We also thank Tíberio Simões, and all the fishermen that collaborated with us during fieldwork.

\section{REFERENCES}

Agardy, T. - 2000. Effects of fisheries on marine ecosystems: a conservationist's perspective. ICES J. Mar. Sci., 57(Suppl. 3): 761-765.

Beukema, J.J. - 1995. The long-term effects of mechanical harvesting of lugworms on the zoo-benthos community of a tidal flat in the Wadden Sea. Neth. J. Sea Res., 33(Suppl. 2): 219-227.

Clarke, K.R. and R.N. Gorley. - 2001. PRIMER (Plymouth Routines In Multivariate Ecological Research) v5: User Manual/Tutorial. PRIMER-E Ltd, Plymouth.

Clarke, K.R. and R.M. Warwick. - 1994. Change in marine communities: An approach to statistical analysis and interpretation. Natural Environment Research Council, Plymouth Marine Laboratory, Plymouth.

Dayton, P.K., S.F. Thrush, T. Agardy, and R.J Hoffman. - 1995. Viewpoint: Environmental effects of marine fishing. Aquat. Conserv. Mar. Freshw. Ecosyst., 5: 205-232.

De Alteris, J., L. Skrobe and C. Lipsky. - 1999. The significance of seabed disturbance by mobile fishing gear relative to natural processes: a case study in Narragansett Bay. In: L. Benaka, (eds.), Fish Habitat: Essential Fish Habitat and Rehabilitation, pp. 224-237. American Fisheries Society, Symposium 22, Bethesda, MD.

Eleftheriou, A. and R. Robertson. - 1992. The effect of experimental scallop dredging on the fauna and physical environment of shallow sandy community. Neth. J. Sea Res., 30: 289-299.

Ferns, P.N., D.M. Rostron and S.H.Y. Siman. - 2000. Effects of mechanical cockle harvesting on intertidal communities. $J$. Appl. Ecol., 37: 464-474.

Gaspar, M.B., M.D. Dias., A. Campos., C.C. Monteiro., M.N. Santos., A. Chicharo and L. Chicharo. - 2001. The influence of dredge design on the catch of Callista chione (L. 1758). Hydrobiologia., 465: 153-167

Gaspar, M.B., F. Leitão., L. Chicharo., M.N. Santos and C.C. Monteiro. - 2003. A comparison of direct mortality inflicted on macrofaunal organisms by three types of dredges used in the Portuguese clam fishery. ICES J. Mar. Sci., 60: 733-742.

Gaspar, M.B and C.C. Monteiro. - 1999. Indirect mortality caused to juveniles of Spisula Solida due to deck exposure. J. Mar. Biol. Ass. UK., 79: 567-568.

Gislason, H. -2003 . The effect of fishing on non-target species and ecosystem structure and function. In: M. Sinclair and G. Valdimarsson (eds), Responsible fisheries in the marine ecosystem, pp. 255-274. Rome, Italy and Wallingford, UK.

Goñi, R. - 1998. Ecosystem effects of marine fisheries: an overview. Ocean. Coast. Manage., 40: 37-64.

Graça, C.M.B.R. - 2001. Contribuição para o estudo do crescimento e reprodução de Ruditapes decussatus (Linnaeus, 1758) $e$ Cerastoderma edule (Linnaeus, 1758) na Ria Formosa. Ph. D. thesis, Univ. do Algarve.

Hall, S.J., D.J. Basford and M.R. Robertson. - 1990. The impact of hydraulic dredging for razor clams Ensis sp. on an infauna community. Neth. J. Sea Res., 27: 119-125.

Hall, S.J and M.J.C. Harding. - 1997. Physical disturbance and marine benthic communities: The effects of mechanical harvesting of cockles on non-target benthic infauna. J. Appl. Ecol., 34: 497-517.

Hall, S.J., M.R. Robertson., D.J. Basford and R. Fryer. - 1993. Pitdigging by the crab Cancer pagurus: a test for long-term, large scale effects on infauna community structure. J. Anim. Ecol., 62: 59-66.

Hiddink, J.G. - 2003. Effects of suction-dredging for cockles on non-target fauna in the Wadden Sea. J. Sea Res., 50: 315-323 
Kaiser, M J., D B Edwards, P J Armstrong, K. Radford, N.E.L. Lough., R.P. Flat and H.D. Jones. - 1998. Changes in megafauna benthic communities in different habitats after trawling disturbance. ICES J. Mar. Sci., 55: 353-361.

Kaiser, M.J., G. Broad and S.J. Hall. - 2001. Disturbance of intertidal soft-sediment benthic communities by cockle hand raking. J. Sea Res., 45: 119-130.

Kristensen, I. - 1957. Differences in density and growth in a cockle population in the Dutch Wadden Sea. Arch.Néerl.Zool., 12 (suppl. 3): 351-453.

Leitão, F.M.S. - 2004. Estudo comparativo da mortalidade induzida pela faca de mariscar e draga de mão na comunidade macrobentónica associada aos bancos de pesca do berbigão (Cerastoderma edule, L. 1758). MSc thesis, Univ. de Coimbra.

Lindeboom H.J and S.J. De Groot. - 1998. The effects of different types of fisheries on the North Sea and Irish Sea benthic ecosystems. NIOZ-Rapport 1998-1RIVO DLO report65 c003/98, 404 pp.

Moore, J. - 1991. Studies on the impact of hydraulic cockle dredging on intertidal sediment flat communities. A report to the Nature Conservancy Council from the Field Studies. FSC/RC/4/91. Council Research Centre, Pembroke, Wales.

Philippart, C.J.M. - 1998. Long-term impact of bottom fisheries on several by-catch species of demersal benthic fish and benthic invertebrates in the South-eastern North Sea. ICES J. Mar. Sci. 55: $342-352$

Piersma, T., A. Koolhaas., A. Dekinga., J. Beukema., R. Dekker and K. Essink. - 2001. Long-term indirect effects of mechanical cockle-dredging on intertidal bivalve stocks in the Wadden Sea. J. Appl. Ecol., 38 (suppl. 5): 976-990.

Rees, E.I.S. - 1996. Environmental effects of mechanized cockle fisheries: a review of research data. Report to the Marine Environmental Protection Division, MAFF. Scholl of Ocean
Sciences, University of Wales, Bangor, UK.

Rostron, D. - 1993. The effects of tractor towed cockle dredging on the invertebrate fauna of LLanrhidian Sands, Burry inlet. Subsea survey. Report Countryside Council for Wales.

Rostron, D. - 1995. The effects of mechanised cockle harvesting on the invertebrate fauna of LLanrhidian Sands. Burry Inlet and Loughor Estuary Symposium, 111-117.

Ruano, F.D.L. - 1997. Fisheries and farming of important marine bivalves in Portugal. NOAA Techical Report NMSF., 129: 191-200.

Seed, R and A.R. Brown. - 1978. Growth as a strategy for survival in two marine bivalves, Cerastoderma edule and Modiolus modiolus. J. Anim. Ecol., 47: 283-292.

Spencer, B.E. - 1996. Clam cultivation: localised environmental effects. Results of an experiment in the River Exe, Devon (19911995). Report Prepared for Directorate of Fisheries Research, Fisheries Laboratory, Conwy.

Spencer, B.E., M.J. Kaiser and D.B. Edwards. - 1998. Intertidal clam harvesting: benthic community change and recovery. Aquac. Res., 29(suppl. 6): 429-437.

Sprung, M. 1994. - Macrobenthic secondary production in the intertidal zone of the Ria Formosa - a lagoon in southern Portugal. Est. Coast. Shelf. Sci., 38: 539-558.

Sprung, M and M. Machado. - 2000. Distinct life histories of peracarid crustaceans in a Ria Formosa salt marsh (S. Portugal). Wetlands Ecol. Manag., 8: 105-115.

Zar, J.H. - 1996. Biostatistical analisys. Prentice-Hall International Inc, New Jersey.

Scient. ed.: J.D. Ros.

Received July 24, 2006. Accepted June 14, 2007.

Published online October 17, 2007. 